\title{
JOURNAL.RU
}

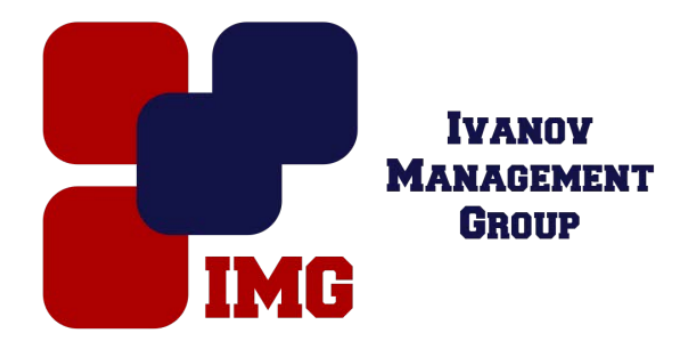

Ермолаева Н.В., Севастьянов Д.А. ВИТИ НИЯУ МИФИ Волгодонск, Россия

doi: 10.18411/lj-31-10-2016-3-04

idsp 000001:lj-31-10-2016-3-04

\section{Портативный газоанализатор на основе смартфона}

Биогенное преобразование органических соединений, содержащихся в грунте, приводит к генерации биогаза, который содержит горючие и токсичные компоненты. Главными из них являются метан(до 40-60 \% объема) и двуокись углерода (CO2); в качестве примесей присутствуют тяжелые углеводородные газы, окислы азота, аммиак, угарный газ, сероводород, молекулярный водород и др. Особенно активно генерация биогаза происходит на насыпных грунтах с примесью строительного, промышленного мусора и бытовых отходов [1]. Кроме того, в грунтовых газах может появиться высокое содержание углеводородных компонентов из-за техногенного загрязнения. В данном случае нефтепродукты из зоны загрязнения могут попасть в грунт под строительными коммуникациями с грунтовыми водами. Генерация в грунтах значительного количества углеводородных газов создает потенциальную опасность их накопления в технических подпольях зданий и инженерных коммуникациях допожаро-, взрыво- и экологически опасных концентраций в случае плохой вентиляции. Вследствие этого, персонал, который проводит различные работы в подвальных помещениях зданий, сооружений и в инженерных коммуникациях, должен быть обеспечен газанализаторным оборудованием.

В настоящее время на предприятиях для идентификации и определения концентрации опасных илегковоспламеняющихся газов и паров (метан, пропан, бутан, и т.д.) используются дорогостоящие газоанализаторы «Сигнал», ШИ-10 и ШИ-11. Существует также ряд индивидуальных газоанализаторов, которые 
рассчитаны на одновременное определение концентрации одного - двух газов. Стоимость этих приборов довольно высокая.

В настоящей работе описано устройство, позволяющее определять концентрацию нескольких газов (метан, пропан, угарный газ, водород), а также измерять ряд физических параметров (температура, влажность).

Предлагаемое нами устройство совместимо с любым смартфоном на ОС Android.Смартфон в данном случае используется для обработки данных от платы Arduino формата UNO и отображения информации на экран.Для измерения влажности и температуры воздуха к плате Arduino подключается датчик DHT11, для идентификации и определения концентрации опасных и легковоспламеняющихся газов и паров в атмосфере используется серия датчиков MQ (MQ-4, MQ-6, MQ-7, MQ-8).

Принцип действия предлагаемого нами устройства следующий.

В диалоговом окне программы, отражаемом на экране смартфона, пользователь выбирает, какой физический параметр он собирается измерить. Далее управляющий сигнал от смартфона поступает на плату Arduino, которая активирует необходимый датчик. Включение питания на датчиках регулируются транзисторами, на которых подается сигнал с цифровых выходов микроконтроллера.После осуществления замеров, информация от датчика поступает на плату Arduino, обрабатывается и отправляется на устройство Android (смартфон). Связь со смартфоном может осуществляться двумя способами - через USB кабель питания и обмена данными, либо по Bluetooth. Следующий этап - обработка информации смартфоном с помощью специальных, предварительно на нем установленных программ. Заключительный этап - графическое отображение информации на экране смартфона.

В случае подключения устройства по USB, смартфон используется как источник питания для микроконтроллера и датчиков. В этом случае к плате Arduinoне требуется отдельно подключать аккумулятор. Однако данный вариант подключения устройства возможен только со смартфонами, которые обладают функцией USBOTG.

Для того, чтобы передавать информацию по беспроводному каналу данных Bluetooth, к плате Arduinoподключается дополнительный модуль НС- 
06.В данном случае наше устройство становится более универсальным в применении, поскольку его можно будет подключать не только к смартфону на операционной системе (OC)Android, но и к устройствам на OC iOS.B данном случае на устройство необходимо предварительно установить программу с функционалом Bluetoothserialmonitor.

\section{Заключение.}

Предлагаемое устройство позволяет определять концентрацию нескольких газов (метан, пропан, угарный газ, водород), а также измерять температуру и влажность воздуха. Результаты измерений выводятся на экран смартфона. Стоимость установки существенно ниже стоимости существующих газоанализаторов. При использовании беспроводного канала данных Bluetooth появляется возможность дистанционного определения концентрации опасных и легковоспламеняющихся газов и паровв подвальных помещениях зданий, сооружений и в инженерных коммуникациях.

\section{Литература}

1. Методика и объемы газогеохимических исследований. [Электронный ресурс //Режим доступа: URL: http://forum.integral.ru>download/file.php?id=6861 